\title{
Pengaruh Model Cooperative Learning Tipe Inside-Outside Circle (Ioc) Terhadap Prestasi Belajar dengan Memperhatikan Minat Belajar Matematika
}

\author{
Lalu A. Hery Qusyairi, Jannati Sakila \\ STIT Palapa Nusantara Lombok NTB \\ heryqusyairi@gmail.com \\ sakilajannati@gmail.com
}

\begin{abstract}
Abstrak: Penelitian ini bertujuan untuk mengetahui: (1). pengaruh model pembelajaran kooperatif tipe inside-outside circle (IOC) terhadap prestasi belajar matematika siswa yang memiliki minat belajar tinggi (2). untuk mengetahui pengaruh model pembelajaran kooperatif tipe inside-outside circle (IOC) terhadap prestasi belajar matematika siswa yang memiliki minat belajar rendah. Jenis penelitian ini adalah penelitian eksperimen semu yang menggunakan desain dua factorial. Jumlah populasinya adalah seluruh siswa kelas XI MA NW Palapa Nusantara Tahun Pelajaran 2017/2018 dengan jumlah 180 siswa. Teknik pengambilan sampel menggunakan teknik cluster random sampling dengan kelas XI IPS 4 sebagai kelas eksperimen dan kelas XI IPS 3 sebagai kelas kontrol. Instrumen pengumpulan data menggunakan angket minat belajar dan tes prestasi belajar matematika. Metode pengujian hipotesis yang digunakan Uji-t dengan taraf signifikansi 5\%. Hasil penelitian ini menunjukkan bahwa: (1). nilai $t_{\text {bitung }}>t_{\text {tabel }}$ yaitu $t_{\text {bitung }}=4,430$ lebih besar dari pada $t_{\text {tabel } 0.05}=$ 2,00484 maka $H_{0}$ ditolak, yang artinya terdapat pengaruh model pembelajaran kooperatif tipe inside-outside circle (IOC) terhadap prestasi belajar matematika siswa yang memiliki minat belajar tinggi (2). nilai $t_{\text {bitung }}<t_{\text {tabel }}$ yaitu $t_{\text {hitung }}=1,703$ lebih kecil dari pada $t_{\text {tabel } 0.05}=$ 2,00484 maka $H_{0}$ diterima, yang artinya tidak terdapat pengaruh model pembelajaran kooperatif tipe inside-outside circle (IOC) terhadap prestasi belajar matematika siswa yang memiliki minat belajar rendah.

Kata Kunci: model pembelajaran kooperatif tipe inside-outside circle (IOC), prestasi belajar matematika, Minat Belajar
\end{abstract}


Pengaruh Model Cooperative Learning Tipe Inside-Outside Circle (Ioc) Terhadap Prestasi Belajar dengan Memperhatikan Minat Belajar Matematika

\section{Pendahuluan}

Undang-Undang No. 20 tahun 2003 tentang Pendidikan Nasional bahwa pendidikan merupakan usaha sadar dan terencana untuk mewujudkan suasana belajar dan proses pembelajaran agar siswa secara aktif mengembangkan potensi dirinya untuk memiliki kekuatan spiritual keagamaan, pengendalian diri, keperibadian, kecerdasan ${ }^{1}$. Lebih lanjut dijelaskan kembali dalam PP No. 19 Tahun 2005 pasal 19 tentang standar proses pembelajaran, bahwa:

proses pembelajaran pada satuan pendidikan diselenggarakan secara interaktif, inspiratif, menyenangkan, menantang, memotivasi siswa untuk berpartisipasi aktif, serta memberikan ruang yang cukup bagi prakarsa, kreativitas, dan kemandirian sesuai dengan bakat, minat, dan perkembangan fisik serta psikologis siswa $^{2}$.

Berbagai upaya pembenahan sistem pendidikan dan perangkatnya di Indonesia terus dilakukan, sehingga muncul beberapa peraturan pendidikan untuk melengkapi dan menyempurnakan peraturan-peraturan yang sudah tidak relevan lagi dengan kebutuhan saat ini. Hal ini dilakukan untuk meningkatkan produktivitas kerja para guru, memberikan kemampuan dasar serta konsep-konsep yang kuat kepada siswa tentang berbagai disiplin ilmu sebagai bekal bagi mereka di jenjang pendidikan yang lebih tinggi, akhlak mulia serta keterampilan yang diperlukan dirinya, masyarakat, bangsa dan negara.

Selama ini di sekolah-sekolah, termasuk Sekolah Menengah Atas (SMA) / Madrasah Aliyah (MA) masih banyak kekurangan fasilitas yang menunjang tercapainya tujuan pendidikan. Seperti halnya sarana dan prasarana pembelajaran baik yang berbentuk fisik maupun non fisik, moral dan material. Dalam bentuk fisik misalnya fasilitas laboraturium yang belum memadai, ketersedian buku-buku pelajaran yang belum mencukupi dan media lain yang mendukung suksesnya tujuan pendidikan khususnya pada mata pelajaran matematika. Sedangkan dalam bentuk non fisik misalnya ketepatan

${ }^{1}$ Undang-undang Nomor 20 Tahun 2003 Tentang Sistem Pendidikan Nasional Pasal 1, Ayat 1.

2 Peraturan Pemerintah No 19 Tahun 2005 Pasal 19 Tentang Standar Proses Pembelajaran 
Lalu A. Hery Qusyairi, Jannati Sakila

metode mengajar sesuai dengan materi pembelajaran inipun sangat mendukung kelancaran dan tercapainya tujuan pendidikan.

Berdasarkan dari hasil observasi dan wawancara, ada beberapa faktor yang menyebabkan model pembelajaran konvensional masih menjadi pilihan utama dalam mentransfer ilmu kepada siswa. Pembelajaran konvensional yang dimaksudkan disini adalah pembelajaran yang umumnya dipergunakan guru yang berpusat padanya, dengan kata lain pembelajaran di kelas yang diawali dengan penjelasan materi pembelajaran memberikan contoh-contoh persoalan dan penyelesaiannya, Selanjutnya guru memberikan kesempatan kepada siswa untuk melakukan tanya jawab berkaitan dengan pokok pembahasan, dan dilanjutkan guru memberikan soal evaluasi ${ }^{3}$.

Faktor pertama yang menjadi kekurangan di MA NW Palapa Nusantara adalah teknik-teknik pembelajarannya masih mengutamakan hasil tanpa memperhatikan proses yang akan membuat siswa memahami dan ingat dalam jangka waktu yang lama. Sehingga minat, antusias, dan motivasi mereka sangat kurang yang mengakibatkan nilai mata pelajaran matematika mereka rendah.

Faktor kedua datang dari guru matematika sendiri. Guru matematika ini terdaftar sebagai guru dibeberapa sekolah madrasah swasta yang ada di kecamatan Keruak dan kecamatan Jerowaru. Berdasarkan hal itu, penggunaan model pembelajaran konvensional merupakan pilihan utama guru dan jauh lebih praktis bila dibandingkan dengan penggunaan model pembelajaran lainnya atau dengan menyiapkan media pembelajaran tambahan, baik dari segi persiapan maupun pelaksanaannya. Alasan bahwa model pembelajaran konvensional merupakan pilihan utama dari guru dapat dibuktikan dengan pengamatan langsung oleh peneliti.

Berdasarkan permasalahan di atas, selama penggunaan model pembelajaran konvensional menjadi pilihan utama dalam mengajarkan konsep-konsep matematika di kelas, maka prestasi belajar matematika dari sebagian siswa memperoleh skor yang rendah tidak dapat dihindari. Pernyataan di atas sangatlah beralasan karena dari data yang

3 Susanto Dwijo \& Septi Mujizem. Optimalisasi Pembelajaran Konvensional Melalui pembelajaran Kontekstual, (Purworejo: FKIP Universitas Purworejo, 2016), 2. 
Pengaruh Model Cooperative Learning Tipe Inside-Outside Circle (Ioc) Terhadap Prestasi Belajar dengan Memperhatikan Minat Belajar Matematika

diperoleh di MA NW Palapa Nusantara, skor siswa yang menempuh ujian nasional pada tahun pelajaran 2015/2016 sebagian ada yang menujukkan skor yang rendah. Berikut ini disajikan hasil UN XII IPA dan IPS khususnya pada mata pelajaran matematika di MA Palapa Nusantara ${ }^{4}$.

Tabel 1. Daftar Hasil UN MA Palapa Nusantara Program Studi IPA \& IPS pada Pelajaran Matematika

\begin{tabular}{|c|c|c|c|c|c|c|}
\hline $\begin{array}{l}\text { Program } \\
\text { Studi }\end{array}$ & Interval & $\begin{array}{c}\text { Katego } \\
\text { ri }\end{array}$ & $\begin{array}{c}\text { Terenda } \\
\mathrm{h}\end{array}$ & $\begin{array}{c}\text { Terting } \\
\text { gi }\end{array}$ & $\begin{array}{l}\text { Rata- } \\
\text { rata }\end{array}$ & Frekuensi \\
\hline \multirow{2}{*}{$\mathrm{IPA}$} & $56-100$ & \multirow{2}{*}{$\mathrm{D}$} & \multirow{2}{*}{17,5} & \multirow{2}{*}{80} & \multirow{2}{*}{51,41} & 9 \\
\hline & $0-55$ & & & & & 14 \\
\hline \multirow{2}{*}{ IPS } & $56-100$ & \multirow{2}{*}{$\mathrm{D}$} & \multirow{2}{*}{10,0} & \multirow{2}{*}{87,5} & \multirow{2}{*}{43,37} & 20 \\
\hline & $0-55$ & & & & & 36 \\
\hline
\end{tabular}

Hal ini senada dengan data hasil mid matematika siswa untuk kelas $\mathrm{X}$ yang menunjukkan rendahnya prestasi belajar siswa. Berikut disajikan hasil pembelajaran matematika dalam tabel $1.2^{5}$.

Tabel 2. Data Prestasi Belajar Siswa di MA Palapa Nusanatara Tahun Pelajaran $2016 / 2017$

\begin{tabular}{|c|c|c|c|c|}
\hline Interval & Rata-rata & Nilai Tertinggi & Nilai Terendah & Frekuensi \\
\cline { 1 - 3 } 5 56-100 & \multirow{2}{*}{40,17} & 75 & \multirow{2}{*}{10} & 10 \\
\cline { 1 - 3 } & & & & 31 \\
\hline
\end{tabular}

Salah satu model untuk mengatasi rendahnya prestasi belajar siswa di atas adalah menerapkan model pembelajaran cooperative tipe Inside-Outside Circle (IOC). Menurut Setyaningsih, Darmianto \& Astuti (2010: 105) Model pembelajaran cooperative tipe Inside-Outside Circle (IOC) adalah model pembelajaran kelas yang dibagi menjadi dua kelas besar. Tiap-tiap kelas besar terdiri dari kelas lingkaran dalam dan kelas lingkaran luar. Kemudian masing-masing kelas besar yaitu anggota kelas lingkaran dalam berdiri melingkar menghadap ke luar dan anggota kelas lingkaran luar menghadap ke dalam.

\footnotetext{
${ }^{4}$ Data Nilai UAN tahun 2015/2016

${ }^{5}$ DataHasil MID Matematika Kelas X tahun 2016/2017
} 
Lalu A. Hery Qusyairi, Jannati Sakila

Supriyani berpendapat bahwa proses pembelajaran Inside Outside Circle (IOC), siswa diberi kesempatan untuk berbagi informasi secara singkat dan teratur dalam bentuk diskusi kelas. Dimana kondisi ini tidak membosankan bagi siswa dan juga membuat siswa terlibat aktif dalam diskusi dan proses pembelajaran. Sehingga siswa akan lebih mudah menemukan, membangun, dan mengembangkan pengetahuan dalam pikirannya. Dengan keterlibatan siswa dalam belajar lebih optimal, menyebabkan pembelajaran yang berlangsung lebih efektif. Pada akhirnya model pembelajaran ini dapat meningkatkan hasil belajar siswa.

Berdasarkan uraian di atas, maka perlunya dilakukan penyelidikan yang dalam pelaksanaan pembelajarannya menggunakan model pembelajaran yang dapat melibatkan siswa secara aktif dalam proses pembelajaran sehingga dapat meningkatkan prestasi belajar siswa. Penggunaan model pembelajaran cooperative tipe Inside-Outside Circle (IOC) diharapkan dapat tercipta suasana belajar yang lebih menarik, menyenangkan bagi siswa ataupun guru, lebih efektif dan menumbuhkan semangat siswa untuk membangkitkan prestasi belajarnya. Model Pembelajaran Koopratif tipe IOC ini di MA NW Palapa Nusantara belum diterapkan oleh para guru dalam melaksanakan Proses Belajar Mengajar (PBM). Sehingga, peneliti ingin melakukan suatu penelitian tentang "pengaruh pembelajaran cooperative tipe Inside-Outside Circle (IOC) terhadap prestasi belajar siswa pada pelajaran matematika dengan memperhatikan minat belajar siswa."

Bertolak dari permasalahan tersebut, maka rumusan masalah dalam penelitian ini adalah sebagai berikut:

1. Apakah terdapat pengaruh model cooperative learning tipe inside-outside circle (IOC) terhadap prestasi belajar matematika siswa yang memiliki minat belajar tinggi?

2. Apakah terdapat pengaruh model cooperative learning tipe inside-outside circle (IOC) terhadap prestasi belajar matematika siswa yang memiliki minat belajar rendah? 
Pengaruh Model Cooperative Learning Tipe Inside-Outside Circle (Ioc) Terhadap Prestasi Belajar dengan Memperhatikan Minat Belajar Matematika

\section{Metode Penelitian}

\section{Jenis dan Desain Penelitian}

Penelitian ini merupakan penelitian eksperimen semu (quasi-experimental) dengan desain desain dua faktorial. Pemilihan desain dua faktorial karena adanya dua variabel bebas yakni minat belajar matematika dengan kategori minat awal rendah dan minat awal tinggi dan penerapan model pembelajaran kooperatif tipe inside-outside circle (IOC). Adapun desain penelitiannya dapat digambarkan dalam tabel berikut.

Adapun desain penelitiannya dapat digambarkan dalam Tabel 3 berikut.

\begin{tabular}{|c|c|c|}
\hline Minat Belajar Metematika & Kelas Eksperimen & Kelas control \\
\hline Minat Awal Rendah & $\mathrm{x}_{1}$ & $\mathrm{x}_{2}$ \\
\hline Minat Awal Tinggi & $\mathrm{x}_{3}$ & $\mathrm{x}_{4}$ \\
\hline
\end{tabular}

\section{Subjek Penelitian}

Populasi dari penelitian ini adalah seluruh siswa kelas XI MA NW Palapa Nusantara tahun pelajaran 2017/2018, dengan jumlah 180 siswa. 108 jumlah siswa perempuan dan 72 jumlah siswa pria.

Teknik pengambilan sampel dalam penelitian ini adalah teknik Cluster Random Sampling. Teknik ini menentukan sampel dalam kelas-kelas populasi. Hal ini dilakukan karena dalam pelaksanaannya peneliti tidak dapat mengambil sampel secara individu dan didasari bahwa karakteristik dari siswa untuk kelas XI relatif sama.

Adapun kelas yang dijadikan sampel dalam penelitian ini adalah kelas XI1 dan kelas XI2. Hal ini karena sampel harus diambil dari populasi yang betul-betul refresentatif dengan tingkat varians yang sama.

\section{Teknik Pengumpulan Data}

Adapun alur dalam proses pengumpulan data, dapat dilihat dalam gambar di bawah ini 
Lalu A. Hery Qusyairi, Jannati Sakila

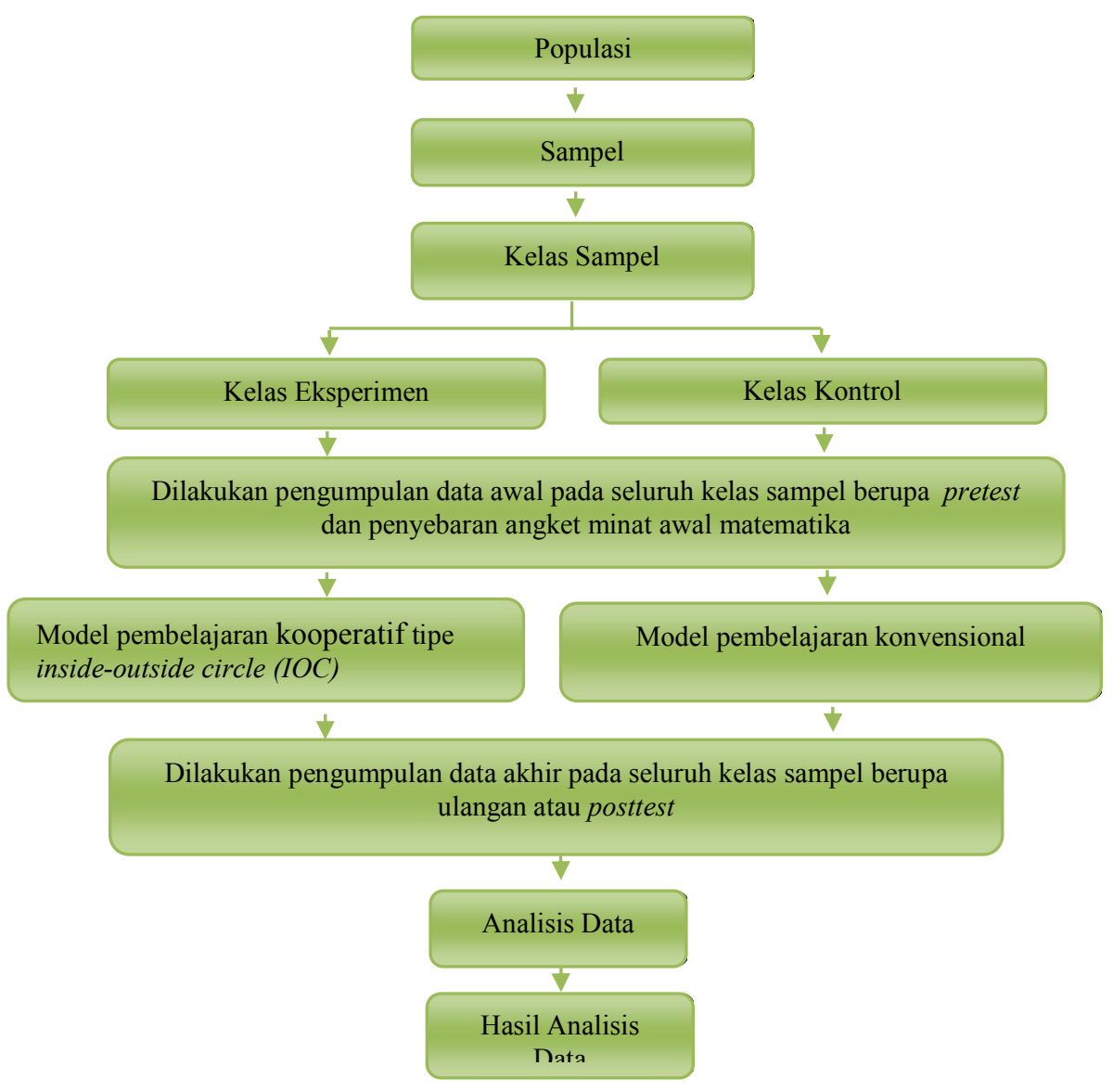

Gambar 4. Alur pengumpulan data

\section{Teknik Analis Data}

\section{Uji Persyaratan Analisis}

Sebelum analisis dilakukan, terlebih dahulu harus dilakukan uji persyaratan analisis. Langkah ini penting karena hasilnya menentukan teknik analisis yang seharusnya dilakukan. Pengujian tersebut meliputi :

\section{a. Normalitas Sebaran Data}

Uji normalitas bertujuan untuk memeriksa kenormalan distribusi populasi yang menghasilkan setiap kelas data sampel. Dengan menguji normalitas, akan 
Pengaruh Model Cooperative Learning Tipe Inside-Outside Circle (Ioc) Terhadap Prestasi Belajar dengan Memperhatikan Minat Belajar Matematika

diketahui apakah sampel yang diambil berasal dari populasi yang berdistribusi normal atau tidak. Uji normalitas dalam penelitian ini diberlakukan untuk penyebaran nilai prestasi belajar matematika. Menurut Kadir ${ }^{6}$ Salah satu yang dipergunakan untuk menguji normalitas data dilakukan dengan menggunakan teknik uji Kolmogorov-Smirnov dengan program SPSS 17.0 for windows. Taraf signifikansi yang dipergunakan adalah 0,05 atau 5\%. Data dapat dikatakan memenuhi syarat populasi berdistribusi normal apabila $\mathrm{D}_{\text {hitung }} \leq \mathrm{D}_{\text {tabel }}$ atau data dapat dikatakan memenuhi syarat normalitas apabila $p>0,05$.

Adapun langkah langkah pengujian normalitas dengan aplikasi SPSS menurut $\operatorname{Kadir}^{7}$ (2016:155) adalah sebagai berikut.

1. Membuka program SPSS 17.0

2. Pada menu SPSS pilih menu analyze, kemudian memilih sub menu Nonparametric Test, pilih Legacy Dialogs, pilih 1 Sampel K-S.

3. Pada Test V aiable List, memasukkan data yang akan diolah

4. Pada Test Distribution, Klik Normal, kemudian klik OK.

\section{b. Homogenitas Varians}

Uji Homogenitas varians dimaksudkan untuk mengetahui apakah sampel yang diambil secara acak berasal dari populasi yang homogen atau tidak. Penentuan homogenitas kelas sampel sangat penting untuk dilakukan. Uji homogenitas varians diberlakukan untuk nilai prestasi belajar matematika. Menurut $\operatorname{Kadir}^{8}$ Salah satu yang dipergunakan untuk menguji homogenitas varians dilakukan dengan teknik Levene's test menggunakan program SPSS 17.0 for Windows. Taraf signifikansi yang dipergunakan adalah 0,05. Data dapat dikatakan memenuhi syarat homogenitas apabila $\mathrm{p}>0,05$.

Adapun langkah langkah pengujian homogenitas dengan aplikasi SPSS menurut Kadir adalah sebagai berikut.

1. Membuka program SPSS 17.0

${ }^{6}$ Kadir, Statistik Terapan, (Jakarta:Raja Grapindo Persada, 2015), 148.

${ }^{7}$ Ibid., 155.

${ }^{8}$ Kadir, Op. Cit, 166-170. 
Lalu A. Hery Qusyairi, Jannati Sakila

2. Pada menu SPSS pilih menu analyze, kemudian memilih sub menu Compare Means dan klik One-Way Anova

3. Memindahkan data yang diolah ke dalam Dependent List dan kedalam Factor, kemudian klik Options

4. Selanjutnya memilih Homogeneity of Variance Test, kemudian klik Continue lalu $O K$.

\section{Uji Hipotesis}

Berdasarkan uji persyaratan analisis yang telah dilakukan maka dapat ditentukan bahwa hipotesis diuji menggunakan uji-t menggunakan bantuan program SPSS 17.0 for Windows.

Adapun langkah langkah pengujian Hipotesis dengan aplikasi SPSS menurut Kadir $^{9}$ adalah sebagai berikut.

1. Membuka program SPSS 17.0

2. Pada menu SPSS pilih menu analyze, kemudian memilih sub menu Compare Means dan klik Independent-Sample T Test

3. Memindahkan data yang diolah ke dalam Test Variable(s) dan Grouping Variable, kemudian klik Define Group

4. Isikan angka 1 pada Group 1 dan angka 2 pada Group 2, kemudian Continue lalu $O K$.

Hasil uji hipotesis ini diketahui (1). Pengaruh model cooperative learning tipe inside-outside circle (IOC) terhadap prestasi belajar matematika siswa yang memiliki minat tinggi dan (2). Pengaruh model cooperative learning tipe inside-outside circle (IOC) terhadap prestasi belajar matematika siswa yang memiliki minat rendah.

Kriteria penerimaan atau penolakan $H_{0}$ pada taraf signifikansi $5 \%$, apabila $t_{\text {bitung }}$ $>t_{\text {tabel }}$ maka $H_{0}$ ditolak, akan tetapi jika $t_{\text {bittung }}<t_{\text {tabel }}$ maka $H_{0}$ diterima. Penerimaan atau penolakan $H_{0}$ juga dapat dilihat melalui probabilitas (signifikansi) yaitu apabila probabilitas (signifikansi) $>0,05$ maka $H_{0}$ diterima, demikian sebaliknya jika probabilitas (signifikansi) $<0,05$ maka $H_{0}$ ditolak.

\footnotetext{
${ }^{9}$ Ibid., 170.
} 
Pengaruh Model Cooperative Learning Tipe Inside-Outside Circle (Ioc) Terhadap Prestasi Belajar dengan Memperhatikan Minat Belajar Matematika

Hipotesis nol $\left(H_{0}\right)$ dan hipotesis alternatif $\left(H_{a}\right)$ yang merupakan hipotesis komparatif dua variabel dalam penelitian ini adalah :

$H_{0}$ : Tidak terdapat pengaruh model cooperative learning tipe inside-outside circle (IOC) terhadap prestasi belajar matematika siswa yang memiliki minat belajar tinggi.

$H_{a}$ : Terdapat pengaruh model cooperative learning tipe inside-outside circle (IOC) terhadap prestasi belajar matematika siswa yang memiliki minat belajar tinggi.

$H_{0}$ : Tidak terdapat pengaruh model cooperative learning tipe inside-outside circle (IOC) terhadap prestasi belajar matematika siswa yang memiliki minat belajar rendah.

$H_{a}$ : Terdapat pengaruh model cooperative learning tipe inside-outside circle (IOC) terhadap prestasi belajar matematika siswa yang memiliki minat belajar rendah.

\section{PEMBAHASAN}

Data yang diperoleh dalam penelitian ini terbagi menjadi dua bagian utama. Data pertama adalah data minat belajar matematika dan data kedua adalah data prestasi belajar matematika meliputi nilai pretest dan posttest. Data minat belajar matematika diperoleh dalam bentuk skor minat. Skor minat diperoleh pada awal pembelajaran, sedangkan nilai pretest dan posttest diperoleh sebelum dan sesudah perlakuan.

\section{Data Minat Belajar Matematika}

Sebaran skor minat awal matematika diperoleh data dari angket yang diisi langsung oleh siswa sebelum diberikan perlakuan dapat dilihat pada tabel 5. berikut.

\begin{tabular}{|c|c|c|c|c|}
\hline \multirow{2}{*}{ Deskripsi } & \multicolumn{2}{|c|}{$\begin{array}{c}\text { Kelas Eksperimen } \\
(\mathbf{n = 3 0 )}\end{array}$} & \multicolumn{2}{c|}{$\begin{array}{c}\text { Kelas Kontrol } \\
(\mathbf{n = 3 0 )}\end{array}$} \\
\cline { 2 - 5 } & $\begin{array}{c}\text { Minat Tinggi } \\
(15)\end{array}$ & $\begin{array}{c}\text { Minat } \\
\text { Rendah } \\
(15)\end{array}$ & $\begin{array}{c}\text { Minat Tinggi } \\
(15)\end{array}$ & $\begin{array}{c}\text { Minat } \\
\text { Rendah } \\
(15)\end{array}$ \\
\hline Rata-rata & 75,44 & 59,17 & 82,06 & 62,56 \\
\hline
\end{tabular}




\begin{tabular}{|l|c|c|c|c|}
\hline Standar Dev. & 5,98 & 4,88 & 0,81 & 1,27 \\
\hline Nilai Maksimum & 88 & 65 & 88 & 66 \\
\hline Nilai Minimum & 68 & 52 & 77 & 58 \\
\hline
\end{tabular}

\section{Data Prestasi Belajar Matematika}

Dalam penelitian ini data prestasi belajar matematika terdiri dari dua jenis yaitu data pretest sebelum dilakukan perlakuan dan data posttest setelah diberikan perlakuan. Data skor minat belajar matematika untuk minat tinggi dapat dilihat dalam tabel 6 . Berikut:

\begin{tabular}{|l|c|c|c|c|}
\hline \multirow{2}{*}{\multicolumn{1}{|c|}{ Deskripsi }} & \multicolumn{2}{c|}{$\begin{array}{c}\text { Kelas Eksperimen } \\
\text { (Minat Tinggi) }\end{array}$} & \multicolumn{2}{c|}{$\begin{array}{c}\text { Kelas Kontrol } \\
\text { (Minat Tinggi) }\end{array}$} \\
\cline { 2 - 5 } & $($ pretest) & (posttest) & (pretest) & (posttest) \\
\hline Rata-rata & 58,53 & 85,27 & 59,87 & 72,60 \\
\hline Standar Dev. & 2,03 & 8,87 & 1,40 & 6,62 \\
\hline Nilai Maksimum & 60 & 98 & 62 & 87 \\
\hline Nilai Minimum & 55 & 72 & 58 & 64 \\
\hline
\end{tabular}

Adapun data pretest dan posttest untuk data skor minat belajar matematika untuk minat rendah dapat dilihat dalam tabel 7 . berikut.

\begin{tabular}{|l|c|c|c|c|}
\hline \multirow{2}{*}{ Deskripsi } & \multicolumn{2}{|c|}{$\begin{array}{c}\text { Kelas Eksperimen } \\
\text { (Minat Rendah) }\end{array}$} & \multicolumn{2}{c|}{$\begin{array}{c}\text { Kelas Kontrol } \\
\text { (Minat Rendah) }\end{array}$} \\
\cline { 2 - 5 } & (pretest) & (posttest) & $\begin{array}{c}\text { (pretest) } \\
\text { (posttest) }\end{array}$ \\
\hline Rata-rata & 59,27 & 78,53 & 59,60 & 73,87 \\
\hline Standar Dev. & 1,67 & 8,21 & 2,29 & 6,71 \\
\hline Nilai Maksimum & 63 & 92 & 64 & 89 \\
\hline Nilai Minimum & 57 & 66 & 56 & 68 \\
\hline
\end{tabular}

Karena data bersifat homogen dan berdistribusi normal. Pengujian hipotesis dilakukan menggunakan uji beda rata-rata atau uji-t (independent sample $t$ test). Untuk 
Pengaruh Model Cooperative Learning Tipe Inside-Outside Circle (Ioc) Terhadap Prestasi Belajar dengan Memperhatikan Minat Belajar Matematika

menghitung koefisien $t$ pada independent sample $t$ test ini digunakan program SPSS 17.0 for Windows.

1. Pengaruh model cooperative learning tipe inside-outside circle (IOC) terhadap prestasi belajar matematika siswa yang memiliki minat belajar tinggi.

Berdasarkan hasil nilai rata-rata Pretest sebesar 58,53 untuk kelas eksperimen dan 59,87 untuk kelas kontrol. Kedua rata-rata kelas eksperimen dan kelas kontrol tersebut juga tidak jauh berbeda dan terletak pada rentang yang sama maka dapat dinyatakan juga bahwa siswa pada kedua kelas tersebut memiliki kemampuan yang sama.

Setelah mengalami proses pembelajaran, siswa dievaluasi melalui penyebaran soal essay. Berdasarkan tes yang telah dilakukan didapatkan nilai posttest sebesar 85,27 untuk kelas eksperimen dan 72,60 untuk kelas kontrol. Dari rata-rata tersebut terlihat bahwa, untuk kelas eksperimen menunjukkan rata-rata prestasi belajar matematika berbeda dengan kelas kontrol.

Berdasarkan nilai posttest, dilakukan uji hipotesis pertama yaitu pengaruh model cooperative learning tipe inside-outside circle (IOC) terhadap prestasi belajar matematika siswa yang memiliki minat belajar minat tinggi. Karena data bersifat normal dan homogen, maka uji hipotesis yang digunakan adalah independent sample t-test.

Berdasarkan uji hipotesis yang telah dilakukan, tampak bahwa terdapat pengaruh model cooperative learning tipe inside-outside circle (IOC) terhadap prestasi belajar matematika siswa yang memiliki minat belajar tinggi, dengan nilai $t$ untuk $d f=28$ adalah 2,0484. Karena nilai $t_{\text {hitung }}>t_{\text {tabel }}$ yaitu $t_{\text {bitung }}=4,430$ lebih besar dari pada $t_{\text {tabel } 0.05}=2,00484$ maka $H_{0}$ ditolak. Dari taraf signifikansi hitung yaitu 0,000 yang nilainya lebih kecil daripada 0,05, juga dapat disimpulkan bahwa $H_{0}$ ditolak, artinya terdapat pengaruh model cooperative learning tipe inside-outside circle (IOC) terhadap prestasi belajar matematika siswa yang memiliki minat belajar tinggi.

Pada awal mulanya dihipotesakan bahwa hasil tes prestasi belajar matematika dengan model cooperative learning tipe inside-outside circle (IOC) yang memiliki minat belajar tinggi akan lebih tinggi dari pada hasil tes prestasi belajar matematika dengan model 
Lalu A. Hery Qusyairi, Jannati Sakila

pembelajaran ceramah. Ada tindakan-tindakan yang lebih diberikan dengan model cooperative learning tipe inside-outside circle (IOC), siswa tidak cepat melupakan apa yang telah diberikan dari pertemuan pertama sampai pertemuan akhir, sehingga dapat dikatakan siswa terlibat aktif dalam proses pembelajaran.

Tipe IOC dilakukan dengan cara, siswa dalam kelas eksperimen dibagi menjadi separuh lingkaran besar dan separuh lingkaran kecil. separuh siswa pada lingkaran kecil duduk mengahadap siswa pada separuh siswa pada lingkaran besar. Dua siswa yang berpasangan dari lingkaran kecil dan besar berbagi informasi. Siswa berada dilingkaran kecil yang memulai. Pertukaran informasi ini bisa dilakukan oleh semua pasangan dalam waktu yang bersamaan. Kemudian, siswa yang berada di lingkaran kecil diam di tempat, sementara siswa berada di lingkaran besar bergeser satu atau dua langkah searah perputaran jarum jam. Dengan cara ini, masing-masing siswa mendapatkan pasangan yang baru untuk berbagi. Sekarang giliran siswa yang berada di lingkaran besar yang membagikan informasi. Demikian seterusnya.

Berbeda halnya dengan model pembelajaran ceramah siswa tidak banyak dilibatkan dalam proses pembelajaran. Guru bertindak aktif memberikan informasi dari materi pertemuan pertama sampai pertemuan akhir, sedangkan siswa mendengarkan apa yang disampaikan guru, sekali-kali siswa diberilkan kesempatan untuk bertanya.

\section{Pengaruh model cooperative learning tipe inside-outside circle (IOC) terhadap prestasi belajar matematika siswa yang memiliki minat belajar rendah.}

Berdasarkan hasil nilai rata-rata Pretest sebesar 59,27 untuk kelas eksperimen dan 59,60 untuk kelas kontrol. Kedua rata-rata kelas eksperimen dan kelas kontrol tersebut juga tidak jauh berbeda dan terletak pada rentang yang sama maka dapat dinyatakan juga bahwa siswa pada kedua kelas tersebut memiliki kemampuan yang sama, meskipun memiliki minat belajar matematika rendah. Nilai rata-rata minat sebesar 59,17 untuk kelas eksperimen dan 62,56 untuk kelas kontrol. Kedua rata-rata minat kelas eksperimen dan kelas kontrol tersebut juga tidak jauh berbeda maka dapat dinyatakan juga bahwa 
Pengaruh Model Cooperative Learning Tipe Inside-Outside Circle (Ioc) Terhadap Prestasi Belajar dengan Memperhatikan Minat Belajar Matematika

siswa pada kedua kelas tersebut memiliki minat belajar matematika yang tidak jauh berbeda.

Setelah mengalami proses pembelajaran, siswa dievaluasi melalui penyebaran soal essay. Berdasarkan tes yang telah dilakukan didapatkan nilai posttest sebesar 78,53 untuk kelas eksperimen dan 73,87 untuk kelas kontrol. Dari rata-rata tersebut terlihat bahwa, untuk kelas eksperimen sebetulnya menunjukkan rata-rata prestasi belajar matematika berbeda dengan kelas kontrol.

Setelah dianalisis kembali dengan menggunakan uji beda rata-rata atau uji-t (independent sample $t$ test) diperoleh kesimpulan bahwa tidak terdapat pengaruh model cooperative learning tipe inside-outside circle (IOC) terhadap prestasi belajar matematika siswa yang memiliki minat belajar tinggi, dengan nilai $t$ untuk $d f=28$ adalah 2,0484. Karena nilai $t_{\text {hitung }}<t_{\text {tabel }}$ yaitu $t_{\text {bitumg }}=1,703$ lebih kecil dari pada $t_{\text {tabel } 0.05}=2,00484$ maka $H_{0}$ diterima. Dari taraf signifikansi hitung yaitu 0,100 yang nilainya lebih besar daripada 0,05, juga dapat disimpulkan bahwa $H_{0}$ diterima, artinya tidak terdapat pengaruh model cooperative learning tipe inside-outside circle (IOC) terhadap prestasi belajar matematika siswa yang memiliki minat belajar rendah.

Pada awal mulanya dihipotesakan bahwa hasil tes prestasi belajar matematika dengan model cooperative learning tipe inside-outside circle (IOC) yang memiliki minat belajar tinggi akan lebih tinggi dari pada hasil tes prestasi belajar matematika dengan model pembelajaran ceramah. Ada tindakan-tindakan yang lebih diberikan dengan model cooperative learning tipe inside-outside circle (IOC), siswa tidak cepat melupakan apa yang telah diberikan dari pertemuan pertama sampai pertemuan akhir, sehingga dapat dikatakan siswa terlibat aktif dalam proses pembelajaran.

Tipe IOC dilakukan dengan cara, siswa dalam kelas eksperimen dibagi menjadi separuh lingkaran besar dan separuh lingkaran kecil. separuh siswa pada lingkaran kecil duduk mengahadap siswa pada separuh siswa pada lingkaran besar. Dua siswa yang berpasangan dari lingkaran kecil dan besar berbagi informasi. Siswa berada dilingkaran kecil yang memulai. Pertukaran informasi ini bisa dilakukan oleh semua pasangan dalam waktu yang bersamaan. Kemudian, siswa yang berada di lingkaran kecil diam di tempat, 
Lalu A. Hery Qusyairi, Jannati Sakila

sementara siswa berada di lingkaran besar bergeser satu atau dua langkah searah perputaran jarum jam. Dengan cara ini, masing-masing siswa mendapatkan pasangan yang baru untuk berbagi. Sekarang giliran siswa yang berada di lingkaran besar yang membagikan informasi. Demikian seterusnya.

Berbeda halnya dengan model pembelajaran ceramah siswa tidak banyak dilibatkan dalam proses pembelajaran. Guru bertindak aktif memberikan informasi dari materi pertemuan pertama sampai pertemuan akhir, sedangkan siswa mendengarkan apa yang disampaikan guru, sekali-kali siswa diberilkan kesempatan untuk bertanya.

Berdasarkan hasil analisis tersebut, prestasi belajar matematika tidak selalu dipengaruhi oleh factor penggunaan model pembelajaran. Factor dari minat belajar siswa juga dapat mempengaruhi prestasi belajar siswa. Siswa yang memiliki minat belajar tinggi akan cendrung memiliki prestasi yang lebih tinggi dibandingkan dengan siswa yang memiliki minat belajar rendah. Untuk meningkatkan minat belajar siswa yang rendah perlunya memperhatikan factor-faktor lain seperti melengkapi sarana-prasarana dan peningkatan profesional guru.

\section{Simpulan}

1. Terdapat pengaruh model cooperative learning tipe inside-outside circle (IOC) terhadap prestasi belajar matematika siswa yang memiliki minat belajar tinggi.

2. Tidak terdapat pengaruh model cooperative learning tipe inside-outside circle (IOC) terhadap prestasi belajar matematika siswa yang memiliki minat belajar rendah. 
Pengaruh Model Cooperative Learning Tipe Inside-Outside Circle (Ioc) Terhadap Prestasi Belajar dengan Memperhatikan Minat Belajar Matematika

\section{DAFTAR PUSTAKA}

Aunurrahman. (2009). Belajar dan Pembelajaran. Bandung: Alfabeta.

Anita Lie. (2008). Cooperative Learning: Mempraktikkan Cooperative Learning Di Ruang-ruang Kelas, Jakarta: Grasindo.

Baharudin \& Esa Nur Wahyuni. (2010). Teori Belajar \& Pembelajaran. Ar-Ruzz Media. Yogyakarta.

Djemari Mardapi. (2004). Penyusunan prestasi belajar. Yogyakarta: Program Pascasarjana UNY.

Lundgren, Linda. (1994). Cooperative learning in the science classroom glenceo. Mac Milan/Mc grow Hill. New York.

Mohammad Surya. (2004). Psikologi pembelajaran dan pengajaran. Bandung: Pustaka bani aksara.

Purwanto. (2009). Evaluasi Hasil Belajar. Yogyakarta: Pustaka Pelajar.

Slameto. (2010). Belajar dan Faktor-Faktor Yang Mempengarubinya. Jakarta : PT. Rineka Cipta.

Sugiyono. (2012). Statistika untuk Penelitian. Bandung: Alfabeta.

. 2011). Metode Penelitian Pendidikan:Sugiyono, Pendekatan Kuantitatif, Kualitatif,dan R\&D, Bandung: Alfabeta.

Undang-undang Nomor 20 Tahun 2003 Tentang Sistem Pendidikan Nasional

Peraturan Pemerintah No 19 Tahun 2005 Pasal 19 Tentang Standar Proses Pembelajaran Wina, Sanjaya. (2006). Strategi pembelajaran berorientasi standar proses pendidikan. Jakarta : penerbit prinada media group.

Williams, R.B. (2002). Cooperative Learning. California: Corwin Press.

Zainal Arifin. (2011), Evaluasi Pembelajaran. Bandung: Remaja Rosdakarya. 